\title{
Author Correction: Genetic architecture of host proteins involved in SARS-CoV-2 infection
}

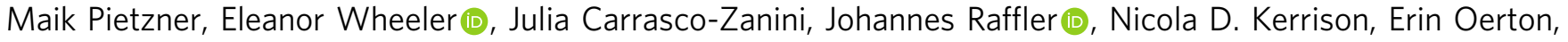 \\ Victoria P. W. Auyeung (1), Jian'an Luan (1), Chris Finan (1), Juan P. Casas, Rachel Ostroff, Steve A. Williams (1), \\ Gabi Kastenmüller (1), Markus Ralser, Eric R. Gamazon (D), Nicholas J. Wareham (D, Aroon D. Hingorani (iD \&
} Claudia Langenberg (D)

Correction to: Nature Communications https://doi.org/10.1038/s41467-020-19996-z, published online 16 December 2020.

The original version of this Article cited "Mehra, M. R., Desai, S. S., Kuy, S., Henry, T. D. \& Patel, A. N. Cardiovascular disease, drug therapy, and mortality in Covid-19. N. Engl. J. Med. 382, e102 (2020)" as Ref. 20. The cited paper was retracted; accordingly, Ref. 20 has been replaced with "Grasselli $\mathrm{G}$ et al. Risk factors associated with mortality among patients with COVID-19 in intensive care units in Lombardy, Italy. JAMA Intern. Med. 180, 1345-1355 (2020)". This has been corrected in the PDF and HTML versions of the article.

Published online: 02 February 2021

\begin{abstract}
(c) (i) Open Access This article is licensed under a Creative Commons Attribution 4.0 International License, which permits use, sharing, adaptation, distribution and reproduction in any medium or format, as long as you give appropriate credit to the original author(s) and the source, provide a link to the Creative Commons license, and indicate if changes were made. The images or other third party material in this article are included in the article's Creative Commons license, unless indicated otherwise in a credit line to the material. If material is not included in the article's Creative Commons license and your intended use is not permitted by statutory regulation or exceeds the permitted use, you will need to obtain permission directly from the copyright holder. To view a copy of this license, visit http://creativecommons.org/licenses/by/4.0/.
\end{abstract}

(C) The Author(s) 2021 